The Philosophical Journal of Conflict and Violence

Vol. I, Issue 2/2017

(C) The Authors, 2017

Available online at http://trivent-publishing.eu/

\title{
Duress as a Defence in a Case of Murder
}

\author{
Maximilian Kiener \\ St. Peter's College, University of Oxford (UK) \\ maximilian.kiener@philosophy.ox.ac.uk
}

\begin{abstract}
This essay defends duress as a complete defence in specific cases of murder through discussing the case of Erdemovic, who was convicted by the International Tribunal for the Former Yugoslavia (ICTY) after he killed innocent people to save his own life. To begin with, I will present two objections to the Court's judgment. Firstly, the Court cannot achieve its objective of deterrence without violating a fundamental legal principle. Secondly, the judgment itself permits that criminals sometimes remove the protecting shield of the criminal law. I will then develop these objections into arguments favouring acquittal and generalise my results.
\end{abstract}

\section{Keywords}

Duress; murder; criminal law; Erdemovic; deterrence; values of criminal law, absolute moral norms.

\section{Introduction: The Case of Erdemovic}

July 1995, during the Bosnian War: soldiers of the Serbian Army capture innocent civilians and line them up for execution without any chance of escape. Drazan Erdemovic is one of these soldiers. He intentionally kills while being fully aware of what he is doing. However, Erdemovic initially refused to kill. Only by threatening him with death for disobedience could higher-ranking officials force him to participate in the massacre. Had Erdemovic refused to kill he would have been shot together with the victims. Hence, there was no chance at all for him to save any of the victims.

Erdemovic was charged with murder and crimes against humanity. He received a sentence of ten years from the International Criminal Tribunal for the former Yugoslavia (ICTY), which was later reduced to five years. The judges held that the circumstances under which Erdemovic acted could not exculpate him with regard to such severe crimes. They may only provide mitigating factors at the level of determining the sentence.

In this essay, I aim to defend the claim that Erdemovic should have been acquitted, thereby supporting duress as a complete defence in particular cases of murder. I will proceed as follows. (I) I will start by presenting the actual judgment in Erdemovic. (II) I will present two objections against this judgment, which no other form of conviction or punishment can avoid. (III) Finally, I argue explicitly for acquitting Erdemovic by defending this position against what I consider the strongest objection and (IV) present my conclusions. Although Erdemovic is a case in international law, the arguments which I will adduce are supposed to be applicable to national law as well, viz. a context outside war that focuses on citizens instead of soldiers. 


\section{The Actual Judgment}

The judges legally classified Erdemovic's situation as an instance of a more general class of acts, namely of offences performed under duress. On the basis of the various judges' pronouncements, the following definition can serve as a basis for further discussion:

Person A commits an offence after and because Person B put forward a threat to inflict harm on Person A unless Person A commits the offence (against a third Person C).

Person B's threat is

- purposeful: it explicitly specifies what is to be done in order to avoid the threat being carried out.

- unlawful: it threatens to inflict a harm that cannot be legally justified.

- linked to imminent harm: it threatens to inflict harm imminently after disobedience without any further chance for Person A to avoid the harm in ways other than doing what the threatening person demands.

- objectively serious: the threatened harm is such that it poses a serious disadvantage to a reasonable person.

- such that one can reasonably assume that it will be carried out.

Erdemovic is like Person A. He committed an offence only after and because he was threatened. Both the offence (killing several innocent people) and the threat (loss of one's life) were particularly severe in Erdemovic's case.

It was the joint opinion of Judge McDonald and Judge Vohrah that provided the basis for the majority vote. ${ }^{1}$ Having surveyed potential sources of law, McDonald and Vohrah concluded that there was no basis in international law for duress to be a complete defence to murder but only to serve as a mitigating factor at the level of sentencing. McDonald and Vohrah subscribed to an "absolute moral postulate" 2 that prohibits intentionally killing innocent people under duress. It is 'absolute' insofar as it does not allow for any kind of "utilitarian logic" 3 to overthrow this prohibition. Only such a principle could do justice to what McDonald and Vohrah identify as "one of (...) [the] prime objectives [of international humanitarian law] (...) [:] the protection of the weak and vulnerable in such a situation where their lives and security are endangered." 4 Therefore, the Court should send a clear message and "give notice in no uncertain terms that those who kill innocent persons will not be able to take advantage of duress as a defence and thus get away with impunity for their criminal acts in the taking of innocent lives." ${ }^{5}$ It is of the utmost importance for the Court that the judgment contributes to a "normative effect which criminal law should have those subject to them", and an "appropriate normative effect upon soldiers." Prevention and deterrence are most central to the judgment's rationale and are considered part of the "policy" of the Court.

\footnotetext{
1 The International Criminal Tribunal for the Former Yugoslavia. Prosecutor v. Drazan Erdemovic. Joint Separate Opinion of Judge McDonald and Judge Vohrah. Case-No. IT-96-22-A, http://www.icty.org/x/cases/erdemovic/acjug/en/erd-asojmcd971007e.pdf (accessed 23 September 2017).

2 Ibid., 83.

3 Ibid., 80.

${ }^{4}$ Ibid., 75.

5 Ibid., 80.

${ }^{6}$ Ibid., 75.

7 Ibid., 75 .

8 Ibid., 88.
} 


\section{Two Objections against the Actual Judgment}

I agree with the Court that in order to achieve an "appropriate normative effect upon soldiers", the judgment must convey the message in "no uncertain terms." Such a requirement is part of what is known as the "rule of law," viz. minimal requirements law has to fulfil in order to guide people's behaviour. It has to be the case that a rational agent could in principle adopt the law's norms and guide his behaviour according to the norms. ${ }^{10}$ However, fulfilling the requirements of the rule of law is not sufficient in order to ensure a proper effect on people's conduct. A norm does not only have to be clearly conceivable for a rational agent but it also has to be worth recognising to a certain extent. In what follows, my critique focuses on the two main possible ways in which the judgment attempts to make law worth recognising.

\section{A. Objection One: Failure of Deterrence on Rational Grounds}

The first way of making law worth recognising is based on the thought that obedience of the norms should not only be conceivable for a rational agent but also rationally attractive to a certain extent. It is by establishing a penal scheme that the criminal law can provide incentives and disincentives so as to encourage rational agents to act in conformity with the law. By conformity, I mean people's behaviour being in accordance with the law without them necessarily sharing the values underlying the criminal law. Conformity is motivated by rational considerations, such as instrumental rationality in pursuing one's goals. ${ }^{11}$ If lawabiding behaviour is rationally attractive, then there is a good "economy" of the law, as it is sometimes put.

Given that the Court imposes punishment and closely connects punishment to the central objective of deterrence, I assume that the Court aims to make law worth recognising on rational grounds in this sense. Unfortunately, the judgment in Erdemovic neither makes obedience to the norm of not killing innocent people rationally attractive nor can it do so without violating another principle which the judgment, and indeed the criminal law as such, embraces. I will support these claims in three steps:

(A.1) I argue that even if Erdemovic had known the actual punishment before killing these innocent people, his reasons for killing would have remained almost completely unaffected.

(A.2) Erdemovic's situation is sufficiently general so as to reveal the criminal law's failure to exert a deterrence effect where it is in needed.

(A.3) Due to a dilemma, there is no acceptable possibility of making the norm against killing innocent persons worth recognising on rational grounds.

\section{A.1 Erdemovic's Situation}

When heard in court, Erdemovic explained his choice in the following way:

Your Honour, I had to do this. If I had refused, I would have been killed together with the victims. When I refused, they told me: "If you are sorry for them, stand up, line up with them and we will kill you too". I am not sorry for myself but for my family, my wife and son who then had nine months,

\footnotetext{
${ }^{9}$ Ibid., 75.

${ }^{10}$ See for instance Lon Fuller, The Morality of Law (Yale University Press, 1964), 33-94. Joseph Raz, The Authority of Law: Essays on Law and Morality (Oxford Clarendon, 1979), 210-229.

${ }^{11}$ See for instance Victor Tadros, Criminal Responsibility (OUP, 2007), 78-79 and 138.
} 
and I could not refuse because then they would have killed me. That is all I wish to add. ${ }^{12}$

On the basis of this statement, there are two rationales that could have motivated Erdemovic's choice:

Self-Interest One's own life has greater weight, or is in a lexical order of values prior to other people's lives (because it is so valuable in itself or because it is a necessary requirement for being able to support one's family). Therefore, any course of action $\mathrm{X}$ that includes preserving one's life, even if this entails a third party's death, is to be preferred to any course of $Y$ which results in one's own death.

Pareto-Life If one course of action $\mathrm{X}$ is such that deviating from $\mathrm{X}$ in favour of any other possible alternative $\mathrm{Y}$ leads only to making some people worse off with regard to preserving their lives without making anyone better off with regard to preserving their lives, $\mathrm{X}$ ought to be performed.

The strategy Self-Interest is about prioritising one's own interests over the interests of others. According to this rationale, killing is the favourable option. Killing allows Erdemovic to preserve his own life and support his family. The sentence Erdemovic receives may make it harder for him to care for his family during imprisonment but certainly does not make it impossible. Most importantly, however, it leaves unaffected the possibility of resuming full care after being released. Killing on the other hand would lead to Erdemovic's death and fully frustrate the ends set out in Self-Interest.

However, also according to Pareto-Life, killing is the favourable option. Pareto-Life aims to achieve what is known as pareto-optimality (viz. an option is pareto-optimal if deviating from it could only lead to making some people worse off without making anyone better off) with reference to preserving lives. In the case of Erdemovic, killing is pareto-optimal in this sense. Deviating from killing (viz. disobeying the higher-ranking officials and refusing to kill) would only lead to one additional person being killed (namely Erdemovic) without making any of the victims better off (as they would have been killed anyway). The imposition of punishment does not affect who will remain alive. So, it does not at all change that killing is pareto-optimal.

Hence, even if Erdemovic had known with certainty that he would receive the sentence imposed on him by the Court, this would have hardly changed the choice based on both rationales.

\section{A.2 Is Erdemovic's Situation Sufficiently General?}

The conclusion that Erdemovic could not have been deterred in the case at hand is so far only a statement about one particular case. With regard to deterrence, it only receives greater significance if Erdemovic is not an isolated instance but something the criminal law needs to account for. After all, the criminal law (in its attempt to make obedience rationally attractive and thereby deter people from disobeying the law) always addresses a set of people and not merely individuals. There will always be some persons or a small group of people who remain immune to the sanctions of the criminal law on a rational basis. Finding one case where the criminal law fails to provide sufficient deterrence is not in itself a serious

12 Statement by Drazan Erdemovic. In: The International Criminal Tribunal for the Former Yugoslavia. Prosecutor v. Drazan Erdemovic. Judgment. Case No. IT-96-22-A, §4, http://www.icty.org/x/cases/erdemovic/acjug/en/erd-aj971007e.pdf (accessed 23 September 2017). 
objection. It is important, however, that the criminal law has a sufficiently great appeal to a substantial majority.

A case could be an isolated exception either due to the features of the situations or the traits of the person involved. The judges acknowledge that a situation like the one Erdemovic found himself in arises with a certain "frequency" 13 in times of armed conflict and thereby accepts a sufficiently great generality. With regard to Erdemovic's rationales, most judges explicitly mention the fact that Erdemovic could not have saved anyone. Moreover, the considerations of pareto-optimality are acknowledged as appealing not only to Erdemovic but also to many other people. Finally, the aim to preserve one's life and to care for one's family cannot be said to be peculiar to Erdemovic either; people share such aims across the board. Hence, both the objective features of the situation as well as Erdemovic's traits are sufficiently general so that the criminal law needs to account for them. The failure to make law worth recognising on rational grounds for Erdemovic is therefore more than an isolated instance of failure. There is a sufficiently wide ranging bad "economy" of law.

\section{A.3 Is There a Way to Improve the Economy of Law?}

It is worth pausing at this point to consider whether the judgment can be improved in terms of making obedience rationally attractive. Consider Sir James Stephen who wrote the following passage when thinking about duress in 1833:

Criminal law is itself a system of compulsion on the widest scale. It is a collection of threats of injury to life, liberty and property if people do commit crimes. Are such threats to be withdrawn as soon as they are encountered by opposing threats? The law says to a man intending to commit murder, If you do it I will hang you. Is the law to withdraw its threat if someone else says, If you do not do it I will shoot you? Surely, it is at the moment when temptation to crime is strongest that the law should speak most clearly and emphatically to the contrary. ${ }^{14}$

This is one of the most challenging and concise passages in Stepehen's work. Let us therefore apply it to Erdemovic's case and the problem of overcoming a bad economy of the law. What would speaking most clearly mean in the case of Erdemovic? It would certainly demand a much higher sentence, most probably capital punishment as nothing short of it seems to be a plausible candidate for improving the economy of law in a case like Erdemovic. At this point I want to dismiss doubts about whether any form of punishment, no matter how severe, could deter a person in such a situation and accept that there might be a possibility of deterrence. The problem I want to raise for this approach is connected to another aspect in the judgment in Erdemovic. The most central principle in the judgment is the "protection of the weak and the vulnerable." 15 Although McDonald and Vohrah mainly

\footnotetext{
13 The International Criminal Tribunal for the Former Yugoslavia. Prosecutor v. Drazan Erdemovic. Joint Separate Opinion of Judge McDonald and Judge Vobrah. Case-No. IT-96-22-A, http://www.icty.org/x/cases/erdemovic/acjug/en/erd-asojmcd971007e.pdf (accessed 23 September 2017), $\$ 76$.

14 Sir James Stephen, A History of The Criminal Law of England. In Three Volumes. Volume II. (New York: Burt Franklin, 1833), 107.

15 The International Criminal Tribunal for the Former Yugoslavia. Prosecutor v. Drazan Erdemovic. Joint Separate Opinion of Judge McDonald and Judge Vobrab. Case-No. IT-96-22-A, http://www.icty.org/x/cases/erdemovic/acjug/en/erd-asojmcd971007e.pdf (accessed 23 September 2017), $\$ 75$.
} 
consider the shot victims to be members of the group of the weak and vulnerable, Erdemovic is also 'weak' (being at the very bottom of a military hierarchy) and 'vulnerable' (higher ranking officials can do many bad things to him). Punishing Erdemovic severely would not only not take into account the fact that Erdemovic is weak and vulnerable, and has been wronged by those threatening him. This position also takes the wrongs done to Erdemovic as an occasion to punish Erdemovic even more severely. In doing so, this position subverts the requirement of supporting those who have been wronged, which is integral to the criminal law ${ }^{16}$ and the 'protection of the weak and vulnerable.'

Hence, even if severe punishment could improve the economy of law, it would betray loyalty to the weak and vulnerable. Therefore, in cases like Erdemovic, there is no possibility of achieving sufficient deterrence on grounds of 'conformity' without betraying the most central principle in the judgment. ${ }^{17}$

\section{B. Objection Two: Criminal Influence}

The justification of a particular judgment does not ultimately rest on its capacity to make obedience rationally attractive. It is certainly a virtue of the criminal law or a particular judgment if it can make norms worth recognising on rational grounds. However, this is not the only basis of justification. A judgment (as well statutes in general) can also be justified if it is the expression of values which the criminal law is committed to and needs to provide a voice for. If this were the case, the "policy" 18 of the Court would not operate by appealing to rationality but rather by appealing to values. Duff, for instance, argued that the criminal law does not only want mere conformity of rational agents but also hopes to secure agreement on its values, that is compliance, which goes beyond conformity. Compliance means that people's behaviour is not only in accordance with the law but also that people share the underlying values of the criminal law. ${ }^{19}$

The judgment in Erdemovic seems to follow such a route when appealing to an "absolute moral postulate" 20 against killing innocent persons. Such an approach could be evaluated either in terms of whether the appeal to values (as opposed to rationality) effectively deters people, or in terms of whether such an appeal to values is justified from the perspective of the criminal law. In this section, I will take the second route. I want to look at whether the judgment makes the norm against killing worth recognising on grounds of a justified claim against Erdemovic and thereby legitimately pursues a "policy" 21 of compliance.

16 See Herbert Fingarette, "Victimization: A Legalist Analysis of Cocercion, Deception, Undue Influence, and Excusable Prison Escape.” Washington and Lee Law Review 42 (1985): 65-118.

${ }^{17}$ My view differs from both Bentham's and Kant's view on duress and punishment insofar as I did not argue that punishment cannot effectively deter in these situations but denied that the form of punishment which may be sufficiently severe is available for the Court in the first place. See Jeremy Bentham, An Introduction to the Principles of Morals and Legislation (Kitchener, Ont. Batoche Books, 1999), XIII. Immanuel Kant, Metaphysik der Sitten. Leipzig (Meiner, 1919), 235-236.

18 The International Criminal Tribunal for the Former Yugoslavia. Prosecutor v. Drazan Erdemovic. Joint Separate Opinion of Judge McDonald and Judge Vobrah. Case-No. IT-96-22-A, http://www.icty.org/x/cases/erdemovic/acjug/en/erd-asojmcd971007e.pdf (accessed 23 September 2017), $\$ 88$.

${ }^{19}$ See for instance Anthony Duff, Punishment, Communication, and Community (OUP, 2003), 80.

20 The International Criminal Tribunal for the Former Yugoslavia. Prosecutor v. Drazan Erdemovic. Joint Separate Opinion of Judge McDonald and Judge Vobrah. Case-No. IT-96-22-A, http://www.icty.org/x/cases/erdemovic/acjug/en/erd-asojmcd971007e.pdf (accessed 23 September 2017), 83 .

${ }^{21}$ Ibid., 88. 
The judgment claimed that Erdemovic should not have killed these innocent people but rather preferred his own death. William Blackstone, cited by McDonald and Vohrah, once gave voice to such a message very clearly when he said of a person acting under duress that "he ought rather to die himself, than kill an innocent." 22 On this assumption, it becomes impossible for Erdemovic to stay alive and act lawfully at the same time. ${ }^{23}$ McDonald and Vohrah call the situation of a person trapped between two threats (the unlawful threat of being killed and the threat of the law's punishment) a "misfortune." 24 This expression is misleading in two ways. Firstly, "misfortune" suggests that the situation at hand is something akin to a natural event rather than something that is deliberately created by people. In Erdemovic's situation it is very clear that protecting one's life becomes unlawful not due to some generic cause. It is deliberately rendered unlawful by criminals, viz. by those higher-ranking officials who threaten Erdemovic. Although these higher-ranking officials cannot make killing innocent people unlawful. Killing innocent people has always been unlawful and the threat does nothing to change this. What they can do, however, is bring people to a situation in which the only way of protecting one's life is an act that is absolutely prohibited by the law. In such a situation the law states that the threatened person must not do what happens to be the only way to protect his life. However, the law cannot do what is necessary to protect the life of threatened person (as the situation is too acute). Hence, criminals can switch off the effective (and still legal) protection of the life of the threatened person and thereby remove the protecting shield of the criminal law. Secondly, the term "misfortune" obfuscates the criminal law's involvement. The misfortune could be a failure of the criminal law itself in its key task to protect lives rather than something that merely happens. Following this "absolute moral postulate", the criminal law itself demands ("ought" in Blackstone) that Erdemovic dies. Although the criminal law does not directly demand that Erdemovic dies, the adherence to an 'absolute' principle requires that killing be prevented at all costs, ${ }^{25}$ which, in this case, means that Erdemovic ought to permit his own killing.

Hence, convicting Erdemovic leads to criminals receiving influence over the person being threatened. This influence is due to a choice made by the criminal law. Surprisingly, McDonald and Vohrah acknowledge criminal influence only in the case of acquittal but not in the case of conviction. They argue that if duress were a complete defence, criminals could confer immunity on people and bar them from legal conviction (and subsequently punishment) by severely threatening them before a crime is committed. However, McDonald and Vohrah completely ignore criminal influence in the case of conviction. Therefore, I reject their rationale that convicting Erdemovic avoids giving influence to criminals (\$74-75). Quite the contrary, it seems that the influence criminals receive over the person being threatened in each case rather suggests acquittal. When acquitting Erdemovic, a situation is created where criminals confer immunity but cannot worsen the position of Erdemovic. Criminals can (if anything) only bar Erdemovic from conviction and

22 See Sir William Blackstone, Commentaries on the Laws of England. A Facsimile of the First Edition of 1765 1769. Volume IV: Of Public Wrongs. (The University of Chicago Press, 1979), 30.

${ }^{23}$ Note that this is true not with reference to a criminal but with reference to a person who has not committed any prior offence.

24 The International Criminal Tribunal for the Former Yugoslavia. Prosecutor v. Drazan Erdemovic. Joint Separate Opinion of Judge McDonald and Judge Vohrah. Case-No. IT-96-22-A, http://www.icty.org/x/cases/erdemovic/acjug/en/erd-asojmcd971007e.pdf (accessed 23 September 2017), 74.

${ }^{25}$ I here follow a formulation that Nagel employed to describe what absolute norms require. See Thomas Nagel, Mortal Questions (CUP, 1979), 62. 
punishment. When convicting Erdemovic on the other hand, a situation is created where criminals worsen the position of Erdemovic by making the protection of his life unlawful. To the extent that worsening is less preferable than immunity, acquitting Erdemovic is to be favoured. Whether or not acquitting is to be preferred, all things considered, still remains to be seen. However, one can state at this point that pursuing a policy of compliance faces serious obstacles of how to justify a severe form of criminal influence. Such severe criminal influence is hard to reconcile with the values inherent to the criminal law.

\section{In Favour of Acquittal}

So far, I have presented two objections to the judgment in Erdemovic. Firstly, punishment cannot achieve sufficient deterrence without subverting the principle of loyalty to the weak and vulnerable. Hence, rational deterrence cannot justify punishment. Secondly, the judgment faces serious justificatory difficulties as it implies a severe form of criminal influence. However, these objections do not present conclusive reasons for Erdemovic's acquittal. It could still be the case that acquitting Erdemovic is even worse than the actual judgment. In this section, I want to fence off such a concern and develop what has been said so far into a direct claim in favour of acquittal. I will do so by responding to what I consider the strongest objection to Erdemovic's acquittal, namely the claim that this would betray the victims. The judgment embraces such a worry by stressing loyalty to the victims most emphatically. I want to respond to the issue of betraying the victims by specifying three senses in which an acquittal could amount to betraying the victims.

\section{A. Betrayal as Failure of Effective Protection}

Betraying the victims could mean failing to contribute to their effective protection. Acquitting Erdemovic and thereby allowing him to defend his life effectively is tantamount to permitting the taking of innocent lives. The judgment may thereby frustrate the task of the effective protection of the victims. Hence, the very attempt of ensuring effective (and still legal) protection of the threatened person may lead to a diminished protection of the lives of the victims. There is indeed no easy way out of this dilemma and it seems almost impossible that the criminal law could allow killing given its responsibility to protect everyone's lives. However, the situation in Erdemovic is such that there may be an exception.

I assume that demanding that the criminal law must not retreat from the protection of the victims requires minimal prospects of successful protection. However, due to the pareto-situation in Erdemovic, nothing which the law can do to Erdemovic can contribute to saving any of the victims' lives. Had Erdemovic accepted the demand of the law and refused to kill, the victims would have been killed a few seconds later together with Erdemovic anyway. Hence, even in the case of perfect compliance, there is no chance at all to protect successfully. Therefore, in terms of effective protection, acquitting Erdemovic is no greater betrayal of the victims than convicting and punishing Erdemovic is.

\section{B. Betrayal as Approval of Killing}

However, even if the Court cannot contribute to the effective protection of the victims, the Court must still refrain from a positive approval of killing the victims. According to a second sense of betraying the victims, one may argue that by acquitting Erdemovic the criminal law approves of killing and thereby almost scorns the victims.

Against this objection I want to claim that acquitting Erdemovic does not mean that the criminal law approves of killing innocent people. The question at stake is not whether the 
criminal law should at all respond to the killing of the victims but rather who is to be addressed when expressing disapproval in the form of conviction and punishment. The criminal law will certainly still punish those who threatened Erdemovic, fully charge them, and thereby express disapproval of initiating a chain of action that led to killing innocent people.

\section{Betrayal as Not Answering Erdemovic's Wronging}

Finally, one may legitimately ask whether not betraying the victims would necessarily require Erdemovic to receive punishment, too. After all, it was Erdemovic who killed these people. He wronged them by taking their lives. ${ }^{26}$ Acquitting him would betray the victims in the sense of not responding to the specific act which wronged them.

An expression of loyalty towards victims should be capable of being understood in the victims' names. Speaking in the victims' names requires pointing not only to the victims' legitimate interests of not being killed but also to the wrongful act of frustrating these interests by killing them. Stating such a wrongful deprivation goes beyond a moral or legal taxonomy of the act. It implies the imperative that the victims should not have been killed, and such an imperative message only makes full sense if the addressee not only caused the wrongful deprivation of the victims' lives but could actually have made a difference, that is prevented the victims from being killed. Otherwise, addressing such a person cannot be considered an expression of what would have been really most important for the victims: not being killed. But as already mentioned, even if Erdemovic had perfectly obeyed the norm against killing it would not have led to the victims being saved. Therefore, convicting and punishing Erdemovic can only in a very restricted sense be considered as speaking in the victims' names. It is limited to pointing to a wrongful deprivation performed by Erdemovic without including the possibility of protecting the victims. Hence, insofar as the message is supposed to express loyalty to victims by speaking in their names, and speaking in their names most importantly focuses on demanding that the victims should not have been killed, Erdemovic is the wrong person to be addressed. Convicting and punishing Erdemovic is not necessary for the most integral part of speaking in the victims' names and therefore in a substantial sense not necessary to avoid betraying the victims.

In summary, acquitting Erdemovic is not a betrayal of the victims understood according to (1) and (2). Even (3) allows, if anything, only for a very restricted sense of the judgment betraying the victims. Hence, there is a comprehensive reply to the strongest objection against acquitting Erdemovic. Convicting and punishing Erdemovic on the other side comes at the cost of allowing for severe criminal influence over the legal and effective protection of Erdemovic's life. This is a particularly undesirable result as the law thereby creates another instance of wronging (criminals depriving Erdemovic of the legal means to protect his life), which needs to be answered, in its very attempt to answer one instance of wronging (killing of the victims). It is therefore disproportionate to insist on Erdemovic's conviction rather than his acquittal. The criminal law should rather express loyalty to the victims by addressing only those who threatened Erdemovic and refrain from splitting punishment between those criminals and Erdemovic, which could eventually reduce the contribution to deterrence and effective protection.

\footnotetext{
${ }^{26}$ Note that this is also true should one find that Erdemovic was morally justified in what he did, all things considered. With regard to the distinction between wrongdoing and wronging, see in particular Thomas Nagel, The View From Nowhere (OUP, 1986), 176. Erin Kelly, "What Is an Excuse?" In Blame. Its Nature and Norms, ed. Justin Coates and Neal Tognazzini (OUP, 2012), 252.
} 
Hence, the Court's policy fails both in terms of 'conformity' and 'compliance.' Erdemovic should therefore be acquitted.

\section{Conclusion}

I would like to conclude by commenting on the nature and scope of my arguments.

The nature of my arguments was genuinely legal. I appealed to what the law is and should be (making law worth recognising, criminal influence, loyalty to those who have been wronged), as opposed to what morality is and should say. Therefore, the conclusion of not convicting or punishing Erdemovic is still compatible with the claim that Erdemovic acted immorally and should be morally blamed. Moral blame is still possible precisely because morality, unlike the criminal law, is not an instrument of the state and is not explicitly charged with the task of effectively protecting lives, liberty, and property of citizens. Morality is about discovering the right actions. As my arguments appealed to genuinely legal aspects (making law worth recognising, criminal influence, loyalty to those who have been wronged) closely associated with the just mentioned task of the criminal law but not necessarily associated with morality, a divergence between the criminal law and morality became possible. Within this legal focus, however, I arrived at a 'justification' rather than an 'excuse'. A defence is a justification if it denies that a person did something wrong and, therefore, should not be blamed for it. A defence is an excuse if it admits that a person did something wrong but nevertheless denies for other reasons that the person should be blamed for having done it. My conclusion is that Erdemovic should neither be convicted nor punished and can therefore resort to a legal, although maybe not a moral, justification. Only on the basis of a justification can one fully avoid the tension between communicating the performance of a legal wrong and being unable to make obedience worth recognising in any of the senses proposed.

The scope of my line of reasoning was restricted to a case of duress (not necessity or selfdefence), more precisely a case of duress in which one's life is at stake and in which there is also a pareto-optimal solution with regard to life. To the extent that other cases differ in these respects my conclusions may not apply. Finally, I have implicitly assumed that Erdemovic's special status as a soldier does not significantly change the situation. Although soldiers are asked to bear greater risks and are subject to different legal (and maybe moral) rules, I assumed that the situation in Erdemovic was so severe as to make the difference between a soldier and a citizen marginal. ${ }^{27}$

However, within these constraints I hope to have made plausible the claim that someone in Erdemovic's circumstances ought to be acquitted.

\section{References}

Bentham, Jeremy. An Introduction to the Principles of Morals and Legislation. Kitchener, Ont. Batoch Books, 1999.

Blackstone, William. Commentaries on the Laws of England. A Facsimile of the First Edition of 1765-1769. Volume IV: Of Public Wrongs. The University of Chicago Press, 1979.

${ }^{27}$ See for instance Luis Chiesa, "Duress, Demanding Heroism, and Proportionality." Vanderbilt Journal of Transnational Law 41 (2008): 772. Thomas Weigend, "Kill or Be Killed. Another Look at Erdemovic." Journal of International Criminal Justice 10 (2012): 1236. A different stance can be found in The International Criminal Tribunal for the Former Yugoslavia. Prosecutor v. Drazan Erdemovic. Joint Separate Opinion of Judge McDonald and Judge Vohrah. Case-No. IT-96-22-A, http://www.icty.org/x/cases/erdemovic/acjug/en/erd-asojmcd971007e.pdf (accessed 23 September 2017), \$69. 
Chiesa, Luis. "Duress, Demanding Heroism, and Proportionality." Vanderbilt Journal of Transnational Law 41 (2008): 741-773.

Duff, Anthony. Punishment, Communication, and Community. OUP, 2003.

Fingarette, Herbert. "Victimization: A Legalist Analysis of Cocercion, Deception, Undue Influence, and Excusable Prison Escape." Washington and Lee Law Review 42 (1985): 65118.

Fuller, Lon. The Morality of Law. Yale University Press, 1964.

Kant, Immanuel. Metaphysik der Sitten. Leipzig. Meiner, 1919.

Kelly, Erin. "What Is an Excuse?" In Blame. Its Nature and Norms, ed. Justin Coates and Neal Tognazzini, 244-262. OUP, 2012.

Nagel, Thomas. Mortal Questions. CUP, 1979. . The View From Nowhere. OUP, 1986.

Raz, Joseph. The Authority of Law: Essays on Law and Morality. Oxford Clarendon, 1979.

Stephen, Sir James. A History of The Criminal Law of England. In Three Volumes. Volume II. New York: Burt Franklin, 1833.

Tadros, Victor. Criminal Responsibility. OUP, 2007.

Weigend, Thomas. "Kill or Be Killed. Another Look at Erdemovic." Journal of International Criminal Justice 10 (2012): 1219-1237.

\section{Acknowledgments}

I want thank Les Green for his astute comments on a previous version of this paper as well as express my gratitude to the audiences at the Workshop for Political Philosophy 2017 at the Europe University of Flensburg, the Ninth European Congress of Analytic Philosophy 2017 at the LMU Munich, the 15th Pavia Graduate Conference in Political Philosophy 2017 at the University of Pavia, and two anonymous reviewers for The Philosophical Journal of Conflict and Violence for their very valuable feedback.

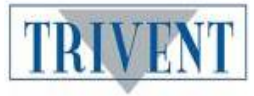

The PJCV Journal is published by Trivent Publishing. 